\title{
Acabaram-se os otários: compreendendo o primeiro longa- metragem sonoro brasileiro
}

\author{
Rafael de Luna Freire Correio'
}

1. Professor adjunto do Departamento de Cinema e Vídeo da Universidade Federal Fluminense (UFF), credenciado ao Programa de Pós-Craduação em Comunicação, Imagem e Informação da mesma universidade. E-mail: rafaeldeluna@hotmail.com 


\section{Resumo}

O filme Acabaram-se os otários (1929), considerado perdido, foi tradicionalmente objeto de equívocos, simplificações ou mal-entendidos pela historiografia do cinema brasileiro. Para uma melhor compreensão do primeiro longa-metragem brasileiro sonorizado, este artigo propõe analisar a produção e a realização desse filme de Luiz de Barros de forma mais abrangente e aprofundada dentro do conturbado contexto de transição do cinema silencioso para o filme sonoro.

\section{Palavras-chave}

Filme sonoro, disco, música caipira, exibiç̧ão.

\section{Abstract}

The film Acabaram-se os otários (1929), considered to be lost, has usually been the object of misunderstandings, errors and simplifications by Brazilian film historians. For a better understanding of the first Brazilian sound feature, this article aims to analyze the movie's production and reception in a deeper and broader way, studying Luiz de Barros's film in relation to the complex context of transition to sound cinema in Brazil.

\section{Keywords}

Sound cinema, disc, film exhibition, Brazilian popular music. 
O filme Acabaram-se os otários (1929), dirigido por Luiz de Barros, entrou para a história do cinema brasileiro como "o primeiro filme completamente sonorizado" feito no país (VIANY, 1959: 98). Entretanto, como muitos outros filmes brasileiros desse e de outros períodos, seus negativos e cópias se perderam e aos nossos dias chegaram somente poucos e breves fragmentos de suas imagens. Como em muitos outros casos também, o desaparecimento dos materiais resultou em interpretações duvidosas sobre a origem, o formato e a repercussão do filme.

Por esse motivo, este artigo partiu de uma ampla pesquisa baseada numa grande variedade de documentos (textuais, imagéticos e sonoros), não restritos somente ao cinema brasileiro, mas que sustentavam o necessário diálogo com áreas como as da história da música popular, do teatro e do disco. A pesquisa de base documental definitivamente forneceu mais subsídios para uma interpretação menos especulativa sobre o filme, atentando especialmente para seu atrelamento às características particulares do contexto histórico, cultural e tecnológico em que ele foi produzido e consumido.

Afinal, apesar da maior parte das imagens de Acabaram-se os otários não ter sobrevivido, foi possível verificar, por exemplo, que as canções apresentadas nele baseavam-se em discos pré-gravados, lançados comercialmente e filmados a posteriori e que ainda existem em vários acervos de discos $78 \mathrm{rpm}$. Já a parte falada sincronizada do filme, também registrada em discos, era considerada inteiramente desaparecida até serem identificadas recentemente três gravações que incluíam até mesmo diálogos do filme.

Em comunicação realizada durante o XVI Encontro da Sociedade Brasileira de Estudos de Cinema e Audiovisual (SOCINE), em outubro de 2012, o pesquisador Rafael de Luna Freire (2013) destacou como o filme de Luiz de Barros constituíase numa produção majoritariamente acompanhada por música não sincronizada, apresentando ainda as gravações Tango mania ("couplet cômico"), A quadrilha ("scena cômica") e Serenata malograda ("scena de gargalhada"). Esses registros estão disponíveis em formato digital na base de dados do acervo do Instituto Moreira Salles (http://acervo.ims.uol.com.br/) e foram identificados como pertencentes à banda sonora original de Acabaram-se os otários, tendo sido realizados especialmente para o filme. 
Pelo menos até a descoberta dessas informações preciosas, a principal - e quase sempre a única utilizada - fonte sobre Acabaram-se os otários era o livro Minhas memórias de cineasta (BARROS, 1978). Distanciado historicamente dos acontecimentos de 1929, o carioca Luiz de Barros (que então vivia em São Paulo) narrou em seu livro a origem do pioneiro filme sonoro de forma gaiata, como o resultado inesperado de uma ocasional aposta:

Um dia, encontrando na rua o Sr. Bruno, que era, naquele momento, diretor das Empresas Cinematográficas Reunidas, que estava entusiasmado com o cinema sonoro, que acabava de chegar, eu lhe disse, confesso que para gozá-lo:

- Ora, Sr. Bruno, não é só americano que faz filme falado. Eu também vou fazer um.

Ele acreditou e, continuando com seu entusiasmo:

-Vai? Como se chama o filme?

E, para gozá-lo ainda mais, respondi:

- ACABARAM-SE OS OTÁRIOS.

- Eu faço negócio no escuro. Vamos ao escritório.

Fui. Conversa vai, conversa vem, saí de lá com negócio fechado e data marcada para a estreia do filme! (BARROS, 1978: 104).

Como evidenciaremos neste texto, o contrato acertado entre João Antonio Bruno - diretor juntamente com Vicente D’Errico, das Empresas Cinematográficas Reunidas - e o realizador Luiz de Barros era mais do que uma aposta fortuita. Mesmo tendo alegado que tudo começou com uma brincadeira por não ter nada anteriormente preparado para a produção, apenas inventando o título jocoso na hora (BARROS, 1967), o diretor não deixou de ver ali uma grande oportunidade. $\mathrm{Na}$ verdade, a tal aposta representava um acordo mutuamente benéfico entre um exibidor e um cineasta visando aproveitar as condições específicas do mercado cinematográfico do país naquele exato momento. Para o cineasta, era uma chance de alavancar um longa-metragem com garantia prévia de exibição (e provável adiantamento de renda), algo importante para qualquer realizador brasileiro naquele momento. Para o exibidor, era uma oportunidade de oferecer um produto exclusivo para o seu circuito de salas que o distinguiria frente aos 
“palácios" paulistanos já aparelhados para os talkies, como o Cine Paramount, e, logo depois, o Cine Odeon, de Francisco Serrador. Acima de tudo, o filme sonoro de Luiz de Barros daria a Reunidas um trunfo na concorrência direta com os demais cinemas da cidade, que, como os dessa empresa, ainda não tinham sido convertidos para o então caro e complexo sistema de projeção sonora.

Este artigo, portanto, examina o filme Acabaram-se os otários de uma forma mais ampla, atentando para os diferentes aspectos de sua realização e recepção no momento particular de transição para o cinema sonoro no Brasil. Desse modo, buscamos desfazer alguns mal-entendidos, imprecisões e generalizações equivocadas a respeito do início da produção de filmes falados brasileiros.

\section{A filmagem}

Diante do seu acerto com o João Antonio Bruno, mais do que apenas realizar um filme falado em português, Luiz de Barros se viu diante do desafio de desenvolver e construir equipamentos nacionais de filmagem e projeção sonora, algo que não existia então em abril de 1929 e que eles precisaram criar ao longo dos três meses seguintes. Os sócios do produtor e diretor nesse empreendimento foram Tom Bill (além de ator, mecânico), José Del Picchia (cinegrafista) e Gustavo Zieglitz, dono da Agência Cinematográfica Pathé, distribuidora de filmes e representante de equipamentos franceses. Comerciante de projetores, Zieglitz era ainda proprietário das oficinas onde foram construídos os aparelhos para filmagem e exibição sonora batizados de Sincrocinex (na grafia da época Synchrocinex) - nome que enfatizava obviamente a atração do sincronismo entre som e imagem. De fato, sincronismo era a palavra que melhor representava o verdadeiro aperfeiçoamento do cinema sonoro frente aos "cinematógrafos falantes" de outrora, tornando-se a palavra da moda naquele momento.

Entretanto, Acabaram-se os otários consistia naquilo que em Hollywood era chamado de "parcialmente dialogado" (part-talkie), formato de muitos dos filmes norte-americanos que estavam chegando às telas brasileiras. Diferentemente dos então ainda pouco frequentes filmes "todos falados" ou "100\% falados" (alltalking), a maior parte do filme de Luiz de Barros era simplesmente musicada 
por discos não sincronizados. Portanto, uma parte da produção foi filmada da mesma forma como se faziam os filmes silenciosos.

Outra parte do filme, porém, foi sincronizada por discos de canções já gravadas, sendo os cantores filmados apenas mexendo os lábios e fingindo tocar os instrumentos. Como se recordou em depoimento o músico Paraguassú ([1974] 2000), nome artístico do cantor paulista Roque Ricciardi (1894-1976), suas cenas foram filmadas num "sítio em Santo Amaro", por uma câmera silenciosa (operada por Del Picchia), com ele tocando um violão e dublando suas próprias músicas que eram executadas pelo alto-falante de uma vitrola em plena locação. Ou seja, o filme utilizava o tradicional método de utilizar discos já gravados para depois filmar a cena correspondente, sendo o som registrado anteriormente às imagens (e não simultaneamente), buscando um sincronismo "artificial” na projeção. Isso que hoje chamaríamos de playback, na época era tido como usar os discos como "ponto", da mesma forma como, no teatro da época, os atores tinham um assistente que, instalado no palco, mas escondido da plateia, os lembravam dos diálogos durante a apresentação da peça.

Por último, outra parte do filme teve discos gravados especialmente para o filme, contendo variados diálogos (FREIRE, 2013). A partir das informações reunidas ainda não é possível afirmar com certeza se, nessas cenas, o registro da imagem e do som foi realizado simultânea e sincronicamente, ou se os diálogos foram gravados antes, com a posterior filmagem dos atores dublando suas próprias falas (o mesmo sistema utilizado para as canções)².

Assim, para a filmagem das cenas sincronizadas - fossem com discos tocando ou sendo gravados na hora - o principal problema técnico era ajustar a velocidade da passagem do negativo pela câmera para que ela se mantivesse sempre constante e em regularidade com a velocidade de execução ou gravação dos discos. Isto teria sido alcançado pelos técnicos Francisco Fuerbach e Kourt Koschar, os chefes mecânicos da oficina de Zieglitz. 
Fossem sincronizados às imagens ou não, os discos do sistema Sincrocinex não eram iguais aos discos do sistema Vitaphone, que vinha sendo instalado nos principais cinemas do Rio e São Paulo. O sound-on-disc, da Western Electric, fazia uso de discos especiais de 33 e 1/3 rpm (rotações por minuto), de maior diâmetro (40 centímetros), com a agulha tocando de dentro para fora no sentido anti-horário, resultando em duração de até 11 minutos - equivalente a um rolo simples de filme 35 mm (300 metros ou 1000 pés). Assim, tocava-se um disco para cada rolo de filme projetado.

Por outro lado, o Sincrocinex utilizava os discos comuns da indústria fonográfica, de menores dimensões ( 25 a 30 centímetros), com maior velocidade (78 rpm) e, logo, com menor tempo de registro (cerca de três minutos), sendo necessários pelo menos quatro discos para se obter a mesma duração de um rolo do filme. Como era divulgado nos jornais, o Sincrocinex era diferente do Vitaphone "por não se poder ainda gravar discos [no Brasil] daquele tamanho e aquela rotação" (Diário Nacional, 14 jul., 1929: 20)³.

\section{Filme caipira}

Um ponto fundamental sobre Acabaram-se os otários refere-se ao gênero caipira ao qual a produção clara e assumidamente se alinhava. Na verdade, a origem do filme de Luiz de Barros estava intrinsecamente ligada a um gênero teatral característico de determinadas salas de espetáculos de São Paulo.

Afinal, o estúdio de filmagem de Luiz de Barros ficava nas dependências do Palacete Santa Helena, na Praça da Sé, que tinha em seu térreo um cineteatro inaugurado em 1926 e arrendado justamente pelas Empresas Cinematográficas Reunidas. Se foi exatamente nesse cineteatro que Acabaram-se os otários estreou, a produção foi filmada num "teatrinho de variedades", localizado embaixo do

3. Nos suportes analógicos, em geral, ao diminuir-se a velocidade de registro e execução, amplia-se a duração da gravação. Assim, quanto mais lentamente um disco rodar no aparelho, isto é, quanto menos rotações por minuto (rpm) ele fizer, mais longo será o seu tempo de registro. A mesma lógica se aplica, por exemplo, às gravações em fitas de vídeo. Basta lembrar das diferentes velocidades e correspondentes durações da fita VHS (Standard Play (SP), Long Play (LP), Extended Play (EP). 
teatro principal, utilizado inicialmente em espetáculos teatrais estrelados por Tom Bill e Genésio Arruda e produzidos pelo próprio Luiz de Barros. Como relatou em suas memórias, foi nesse teatrinho que ele montou seu laboratório cinematográfico (BARROS, 1978, p. 103).

Apesar de dotado de luxo e elegância, o cineteatro Santa Helena, pouco depois de sua inauguração, adquiriu um contraditório tom popular e caipira, representativo da decadência prematura do centro velho de São Paulo. Nos anos seguintes, a sala de espetáculo acabaria se destacando "por sediar apresentações dos grandes nomes da música caipira: Cornélio Pires e seus 'causos', o duo Jararaca e Ratinho, a trupe na qual se destacaria mais tarde o comediante Mazzaropi" (CAMPOS; PERRONE, 2006, p. 146 -156).

A ligação entre palco e tela fica mais evidente pelo fato de Lulu de Barros ter utilizado em seu filme o mesmo tipo de música e o os mesmos astros - Tom Bill, Genésio Arruda e Vicente Caiafa (ou Vicenzo Caiaffa) - de espetáculos que ele próprio vinha encenando no Moulin Bleu, na Praça da Sé, número 47 (o cineteatro Santa Helena ficava no número 13). Mesmo nas primeiras semanas após o lançamento de Acabaram-se os otários entre agosto e setembro de 1929, os astros do filme permaneceram apresentando espetáculos de variedades, em sessões contínuas, com ingressos populares, na mesma rua do cinema em que ele estava sendo exibido.

Além disso, o gênero caipira ao qual Acabaram-se os otários se alinhava - tanto por sua trama, quanto pelos artistas e músicas - também galgava exatamente naquele momento enorme popularidade na indústria de discos, sobretudo através da atuante figura de Cornélio Pires.

Conforme Rosa Nepomuceno, "Cornélio Pires foi o maior divulgador da cultura caipira nas primeiras décadas do século. Escreveu livros, fez palestras e representou roceiros em monólogos criados por ele" (1999, p. 101). Adorado pelas plateias, mas visto com reservas por outros escritores, as lucrativas criações de Cornélio foram descritas, por exemplo, em carta de Monteiro Lobato, em 1918: "O caboclo de Cornélio é uma bela estilização, sentimental, poética, ultrarromântica, fulgurante de piadas - e rendosa. O Cornélio vive, e 
passa bem, ganha dinheiro gordo, com as exibições que faz do 'seu caboclo'”. Dá caboclo em conferências a 5 mil-réis a cadeira e o público mija de tanto rir. (SCHVARZMAN, 2010, p. 6).

Inspirado pelos documentários brasileiros exibidos na Exposição de 1922, Cornélio decidiu investir no cinema, iniciando a realização de Brasil pitoresco: viagens de Cornélio Pires (direção de Cornélio Pires e José Palácios, 1925). Além de codirigir a película, Cornélio também atuou frente à câmera, fazendo o papel de guia do espectador por diversas cidades do Brasil, apresentando costumes, paisagens e tipos humanos curiosos e típicos de cada região (SCHVARZMAN, 2010). A participação de Cornélio certamente não ficou restrita às imagens da tela muda, pois as exibições do filme eram frequentemente enriquecidas pela sua consagrada verve, já que, "diretor e principal personagem do filme, ele em geral antecedia as projeções fazendo uma pequena palestra" (SOUZA, 2009, p. 19)4.

Se Sheila Schvarzman indicou como Cornélio fez "do filme um novo suporte para suas apresentações" (SCHVARZMAN, 2010, p. 9), o folclorista, particularmente atento aos novos e modernos meios de comunicação, seguiu buscando outras possibilidades de expandir e diversificar o acesso do público à sua fértil e lucrativa obra caipira. Assim, em 1929, o folclorista decidiu encomendar, com recursos próprios, a gravação e prensagem através do moderno processo elétrico de seus cinco primeiros discos no estúdio e na fábrica da Columbia. Como um pioneiro produtor independente (e eficiente "cavador"), ele mesmo bancou, com dinheiro emprestado de um amigo, a iniciativa de gravar com o grupo "Turma Caipira Cornélio Pires" - composto por vários cantores e duplas caipiras - uma série de anedotas, desafios, declamações, canas-verdes e cateretês, além da primeira moda de viola registrada em disco (NEPOMUCENO, 1999, p. 110; MORAES, 2000, p. 5). 
O investimento valeu à pena e o sucesso de faixas como "Simplicidade do caipira" ou "Numa escola sertaneja" foi enorme, sendo descrito na época pelo jornal O Paiz:

Cornélio Pires teve a fortuna de descobrir e saber aproveitar-se de um magnífico filão de ouro: o gênero caipira. Os seus livros em que conta com certa graça coisas dos nossos sertanejos, são sempre procurados. As suas palestras sobre anedotas dos matutos não fazem menor sucesso. Assim, pois, é natural o êxito que estão obtendo os discos em que a Columbia está gravando piadas e ditos caipiras contadas por ele (O Paiz, 1929, p. 10).

Um ano depois, a Columbia já custeava a gravação de novos discos de Cornélio Pires, que passavam da segunda dezena e mantinham o sucesso:

O nosso inconfundível "rei do humorismo", profundo conhecedor de nosso "folk-lore" regional, tem, sem dúvida, feito a Columbia vender discos em penca, pois é um gênero que conta com imenso público. São chapas que desopilam os apreciadores desta forma de rir e que servem para muitos sentirem de perto a inteligência e a manha de nosso sertanejo, através, geralmente, de interessantes anedotas caipiras (Phono-arte, 1930, p. 30).

Desse modo, embora Acabaram-se os otários se aproximasse de um gênero de já longa tradição na cultura brasileira - incluindo até o cinema, desde o então distante Nhô Anastácio chegou de viagem (com direção de Julio Ferrez, 1908), por exemplo -, a música caipira, em particular, passava a ser crescentemente consumida pelas camadas urbanas num momento de acentuada expansão da indústria fonográfica brasileira. Em meio ao sucesso de vendas tanto de discos humorísticos (Procópio Ferreira, Pinto Filho, Batista Júnior, Alfredo Albuquerque, etc) quanto de música regional (Turunas de Mauricéia, Bando dos Tangarás, Jararaca e Ratinho, Patrício Teixeira, Mandi e Sorocabinha, etc), os discos de canções e anedotas caipiras revelavam particular êxito comercial.

Acabaram-se os otários revela-se, portanto, um filme musicado e falado plenamente inserido nessa voga de música regional, da mesma forma, por exemplo, que um dos curtas realizados por Paolo Benedetti, em setembro de 
1929, com o Bando dos Tangarás tocando o lundu "Vamos falá do norte".

Surpreendentemente, as imagens desse curta foram as únicas de toda a produção sonorizada da Benedetti-Film que sobreviveram ${ }^{5}$.

Menos de dois anos depois de Acabaram-se os otários e Vamos falá do norte, o longa-metragem inteiramente sincronizado Coisas nossas (com direção de Wallace Downey, 1931) ainda investiria na mesma vertente sertaneja, especialmente na longa sequência em que Jararaca e Ratinho alternam causos e piadas com canções de viola. Mas além da música, também o fio de história assumidamente simples e despretensiosa do filme de Luiz de Barros ajudava a deixar o "tom popular e caipira" ainda mais claro.

Afinal, a trama de Acabaram-se os otários era assumidamente despretensiosa: “Espetáculo para distrair o espírito e não para complicar o cérebro do povo”, justificava o jornal Folha da Manhã (1929, p. 6). No filme, Bentinho Samambaia (Genésio Arruda) era um "caipira da gema" da cidade de Pindurassaia que, junto com o italiano sabido Xixilio Spicafuoco (Tom Bill), acabava ludibriado em São Paulo por um espertalhão que tentava lhe vender um bonde, numa ilustração da conhecida piada. Junto com Grilo (Vicente Caiafa), Bentinho e Xixilio viviam peripécias nas ruas, parques e cabarés da grande cidade. Eram destacadas as cenas em que os dois tentavam depenar uma galinha com uma gilete, assim como a longa sequência, completamente falada - aliás, provavelmente a única com diálogos -, num “cabaré alegre". Os personagens eram arrastados para lá por duas belas mulheres e acabavam perdendo seus últimos vinténs. Mas neste cabaré, indignado com os tangos e black-bottons estrangeiros, Bentinho promovia uma sensacional quadrilha, sendo a dança caipira e o solo de pistom desafinado de Tom Bill interrompidos pela gargalhada dos assistentes ${ }^{6}$.

5. Almirante, um dos integrantes do Bando dos Tangarás, juntamente com Noel Rosa e João de Barro, entre outros, lembrou-se que a filmagem de quatro números pelo Bando dos Tangarás ocorreu "num dia de setembro", no quintal da casa do fotógrafo, no Catete, com "um velho gramofone no chão a rodar os discos, com as cinco figuras, inteiramente mudas, apenas gesticulando as cantigas e mal soando os instrumentos" (ALMIRANTE, 1977, p. 157). A canção "Vamos falá do norte" havia sido lançada como o lado A do disco Parlophon, n. 13010, de 1929.

6. Como apontou José Geraldo Vinci de Moraes (2000: 6-8), o amplo espectro sociocultural da cidade de São Paulo era evidenciado na mistura de personagens caipiras e estrangeiros e no cruzamento entre a música popular sertaneja e as referências estabelecidas. Esse aspecto claramente presente na obra de Paraguassú,é facilmente notado também em Acabaram-se os otários através da presença do italiano Xixilio 
No final do filme, o caipira vivido por Genésio Arruda cantava "Eu deixei de ser otário", enquanto ao longo da projeção havia ainda a execução de "Bem-tevi” e “Triste caboclo", interpretadas por Paraguassú, entre outras canções?.

\section{Exibição}

Acabaram-se os otários estreou em São Paulo, com "record de bilheteria", em 2 de agosto de 1929, ficando em cartaz no cineteatro Santa Helena por surpreendentes 52 dias. Segundo Luiz de Barros (1967), a Reunidas the ofereceu o cinema lançador do circuito, o Cine República, mas ele preferiu o menos requisitado, que era o Santa Helena, "para ficar o tempo que fosse preciso". O sucesso foi inesperado e estrondoso, com a polícia sendo chamada para conter a multidão e a produção da Sincrocinex rendendo um “dinheirão”, como lembraria o cantor Paraguassú ([1974] 2000). Em pouco mais de um mês o filme já teria sido visto por 35 mil espectadores. Após permanecer em cartaz no Santa Helena de 2 de agosto a 22 de setembro - uma carreira absolutamente excepcional -, Acabaram-se os otários foi exibido em dezenas de outras salas paulistanas nas semanas seguintes (BERNARDET, 1979: s.p.).

O fato é que, através do Sincrocinex, Luiz de Barros levava um filme falado em português a todo o circuito das Empresas Cinematográficas Reunidas. Àquela altura, apenas o Cine República tinha sido convertido para o cinema sonoro, com sua aparelhagem sendo inaugurada justamente no começo de agosto de 1929. Mas nenhuma das demais salas do amplo circuito Reunidas estava equipada para a projeção desse tipo de filmes, sendo então programadas para exibirem os da Sincrocinex. Assim, ao "fazer o circuito", Acabaram-se os otários apresentava para inúmeras plateias paulistanas não apenas o primeiro 
filme falado em português, mas o primeiro filme falado em exibição naquelas salas - isto é, o primeiro contato de grande parte dos espectadores com o próprio cinema sincronizado, mesmo que improvisadamente através de discos 78 rpm.

No Rio de Janeiro, o filme estreou em 26 de setembro de 1929, no Cine Rialto, cinema lançador da empresa Exibidores Reunidos Sociedade, de Luiz Severiano Ribeiro, que vinha exibindo basicamente filmes europeus silenciosos em meio à febre dos talkies norte-americanos. A produção da Sincrocinex repetiu na capital federal de então o sucesso de público. O jornal O Paiz (1929, p. 20) informou que 5.324 pessoas já tinham visto Acabaram-se os otários em seus três primeiros dias em cartaz. O filme ficou em exibição no Rialto por mais de uma semana, sendo depois lançado em diversos outros cinemas cariocas que também não tinham ainda instalado projeção sonora.

Em 13 de outubro, ele estava em exibição no Cine Theatro Íris, sala de João Cruz Júnior arrendada à mesma Exibidores Reunidos Sociedade. Dias depois, um anúncio da Botelho Film Ltda oferecia Acabaram-se os otários para exibição em cinemas do "Distrito Federal e Estados do Rio de Janeiro, Minas Gerais e Espírito Santo", afirmando que a produção da Sincrocinex tinha rendido fabulosos 450 contos de bilheteria somente no Santa Helena e no Rialto (Correio da manhã, 1929, p. 8)

Acabaram-se os otários foi exibido no Rio de Janeiro, entre outubro e novembro de 1929, em outras salas do mesmo circuito de Luiz Severiano Ribeiro, entre as quais os cinemas Centenário, Guanabara e Tijuca, que, assim como o Rialto e o Íris, não tinham ainda projetores sonoros.

Se a recepção do filme pelas plateias populares - a julgar pelo sucesso de bilheteria e pelas inúmeras reprises - foi efusiva, o julgamento de muitos críticos foi bastante severo. Numa retrospectiva do cinema nacional feita em 1929, o rigoroso Octávio de Faria, por exemplo, chamou Acabaram-se os otários de "pachouchada ridícula", criticando a tentativa de se fazer um cinema no mesmo (baixo) nível do teatro nacional, recusando-se até mesmo a comentar o filme: "É incrível de patetice, de idiotices, de abobalhamento" (O Fan, 1930, p. 8). 
Entretanto, fora as críticas ao inegável tom de comicidade popular do filme - o que era combatido pela sua publicidade que sempre afirmava a assumida simplicidade e despretensão da produção -, o que foi mais destacado em Acabaram-se os otários eram "as melhores canções do nosso interlan” e os "números de canto tipicamente folk-loristas". O grande atrativo do filme de Luiz de Barros eram, sem dúvidas, as "belas canções brasileiras" e o fato de ser falado em português - traços valorizados por uma crítica "patriótica”, e possivelmente condescendente, algo que o já citado Octávio de Faria combatia ferozmente. Por outro lado, esses elementos de identificação certamente tinham o seu valor, como reconheceu o crítico de Fon-Fon! (1929, p. 70): “O enredo vale pouco, já o dissemos, mas as canções, caracteristicamente nacionais, encantaram o numeroso público que viu o film".

Tendo como principal atração a música caipira, associada especialmente ao interior de São Paulo, Acabaram-se os otários chegou a ser definido em seu lançamento no Rio de Janeiro como "um filme regionalista, da vida paulistana, o que justifica o sucesso que na cidade de S. Paulo obteve" (Fon-Fon!, 1929, p. 70).

De qualquer modo, a música executada pelos discos elétricos era tida realmente como um dos principais atrativos de Acabaram-se os otários, até porque Luiz de Barros não teria sido o responsável pelo "primeiro" filme brasileiro falado, conforme afirmava a já citada crítica de Fon-Fon!: "É o primeiro film sincronizado brasileiro - diz-se. Isto não é rigorosamente verdadeiro. O Rio já viu, em aparelho nacional, films sincronizados em português".

De fato, outras salas cariocas já vinham exibindo filmes curtos sonoros, espécies de "proto-videoclipes", produzidos pelo Circuito Nacional de Exibidores (CNE) ou pelo já mencionado Paolo Benedetti. Entretanto, justiça seja feita, o filme de Luiz de Barros foi devidamente anunciado na imprensa carioca como o "primeiro grande filme brasileiro cantado e falado em português" (Gazeta de Notícias, 1929: 5. Grifo nosso). Ou seja, o primeiro longa-metragem sonoro nacional.

Além disso, diferentemente dos filmes do CNE e das primeiras experiências de Benedetti, Luiz de Barros seria reconhecido por ter dado um passo a frente, não somente utilizando discos pré-existentes, mas gravando discos especialmente 
ano 2 número 3

Dossiê

para o seu filme, inclusive com diálogos. Assistindo a Acabaram-se os otários no Rio de Janeiro, Pedro Lima, da revista Cinearte, foi um dos que notou o relativo avanço de Luiz de Barros frente aos concorrentes, dizendo que seu filme não era apenas um "disco ilustrado", mas tinha "história, cenário, intérpretes", ainda que com poucas sequências faladas. Ou seja, era um filme narrativo, com o som subordinado não simplesmente às imagens, mas, acima de tudo, à história. Além do mais, ressaltava o crítico Octávio Mendes, não era um filme “impróprio", como os eram os espetáculos teatrais de Genésio e Tom Bill, frequentemente entremeados a nus artísticos. Tratava-se, na verdade, de uma fita "decente e até ingênua". Por outro lado, dentre as primeiras experiências sonoras brasileiras, Acabaram-se os otários era também a obra que contraditoriamente mais deixava a desejar na opinião de Pedro Lima, apresentando uma direção completamente falha e mostrando uma São Paulo de "fundo de quintal" (Cinearte, 30 out. 1929, p. 5; Cinearte, 18 set. 1929 , p. 20).

\section{A projeção}

Ao comercializar o Sincrocinex, além de levar a cópia de seu filme, Luiz de Barros também ficava encarregado de instalar seu sistema de projeção sonora nas salas onde Acabaram-se os otários seria exibido. Assim, da mesma forma como ocorria nos primórdios do cinema em sua fase inicial itinerante, o produtor Luiz de Barros e seus sócios ofereciam aos empresários, em 1929, um pacote completo: o filme, o equipamento de projeção e os operadores para manejarem o maquinário.

Em meio à chegada do cinema sonoro ao Brasil, o filme sincronizado nacional era um produto destinado às salas de exibição menos capitalizadas - o circuito mais popular - que tinham no Sincrocinex uma alternativa para concorrerem com os novíssimos talkies de Hollywood. As cópias destes últimos vinham sendo alugadas pelos distribuidores a preços bem mais elevados do que os filmes silenciosos. Dessa forma, o Sincrocinex deve ser compreendido no contexto em que vários exibidores brasileiros tentavam adquirir contrafações nacionais dos caros projetores Vitaphone para concorrerem com a febre do cinema sonoro através de exibições de filmes mudos acompanhadas por discos (FREIRE, 2012). 
Não à toa, a questão técnica mais complexa do Sincrocinex era a construção de um projetor que funcionava sincronicamente a uma vitrola ligada a altofalantes. Em julho de 1929, o técnico José Del Pichia revelava que ele e seus sócios ainda estavam concluindo a complexa construção da aparelhagem de projeção, enquanto os equipamentos de filmagem já estavam prontos havia mais de um mês (Correio Paulistano, 1929, p. 10).

Aliás, um artigo sobre a produção do filme revelava que a maior dificuldade técnica tinha sido acertar "a normalidade da marcha do motor que aciona as agulhas, afim de que as quedas de voltagem não produzissem variações nas marchas, o que faria desafinar os discos" (Folha da Manhã, 1929: 6). Esse aspecto do cinema sonoro envolvia o trabalho com eletricidade, o que demandava conhecimentos especializados e atualizados. Se os técnicos cinematográficos geralmente lidavam com questões ligadas à mecânica, química e ótica, para lidar com o som tornavase necessário contratar profissionais de outras áreas. Também não à toa, a "parte rádio (som)" de Acabaram-se os otários, - aquela que envolvia a transmissão e amplificação elétrica do som, o controle de volume etc. -, tinha ficado a cargo dos técnicos de rádio Moacyr Fenelon e Romeu Muniz Barreto, responsáveis pela construção dos amplificadores e alto-falantes (Diário Nacional, 1929, p. 20).

Até Acabaram-se os otários, os pioneiros do cinema sonoro no Brasil, entre os quais as produções da CNE e da Benedetti-Film, tinham se dedicado a realizar curtas-metragens limitados pela duração máxima do registro sonoro, isto é, os discos de 78rpm com cerca de 3 minutos. Sendo um longa-metragem e sem acesso aos discos Vitaphone que tinham a duração de um rolo cinematográfico, os produtores de Acabaram-se os otários se deparavam com um grande problema. Em depoimento ao Museu da Imagem e do Som, Luiz de Barros declarou expressamente: "Como os discos eram curtos, a projeção é que era a história!" (BARROS, 1967). Em suas memórias, o diretor explicou mais detalhadamente como lidou com essa questão:

Isso foi resolvido da seguinte maneira: o operador colocava no projetor número um as cenas sincronizadas, como disse, acertando o start do disco e do filme. Enquanto essa cena era projetada, ele colocava no projetor número 
dois a cena intermediária não sincronizada e no outro toca-discos a música que a devia acompanhar. Quando no projetor número um a cena chegava ao fim, ele passava para o projetor número dois, como até hoje se faz na passagem de uma parte a outra. Enquanto essa cena era projetada, ele acertava o start do filme e do disco da segunda cena sincronizada e, no final desta, tornava a passar para o projetor número dois, onde a outra cena musicada já estava preparada. E assim por diante! (BARROS, 1978, p. 105-106).

Com base no depoimento de Luiz de Barros (1967), podemos tentar resumir ainda mais o procedimento de projeção do Sincrocinex: num rolo foram reunidas todas as cenas faladas, cada uma com duração de cerca de 3 minutos, com espaço entre elas. Este rolo ficava no projetor sincronizado a um toca discos. Em outro projetor era colocado um rolo com as "as cenas mudas apenas musicadas", isto é, aquelas a serem acompanhadas por discos não sincronizados.

Assim, apenas um projetor - aquele que exibia as canções ou diálogos sincronizados - devia manter a correspondência exata com a velocidade do tocadiscos acoplado a ele. Luiz de Barros esclarece novamente: “Em um outro rolo coloquei as cenas mudas que eram acompanhadas, na tela, por músicas tocadas por outro toca discos, não sincronizadas" (BARROS, 1976, p. 69. Grifo nosso).

Desse modo, era alternada uma cena sincronizada - de curta duração - com outras cenas, possivelmente mais longas, não sincronizadas. Enquanto essas "cenas mudas" eram exibidas, trocava-se o disco e preparava-se o projetor "número um" para a próxima cena sincronizada. Ou seja, era um processo extremamente trabalhoso e complicado, com um projetor sendo utilizado por apenas 3 minutos (duração do disco 78 rpm) e não por cerca de 10 minutos, como no Vitaphone.

Diante dessa complexidade técnica, devem ser revistos os julgamentos mais apressados de que Acabaram-se os otários era uma produção rápida, barata e improvisada. Reportagens da época estimavam que toda a aparelhagem do Sincrocinex tinha custado mais de 100 contos de reis. Mesmo que possivelmente inflacionado para fins publicitários, trata-se de uma escala de valor bastante alta para o cinema brasileiro da época. Se o filme paulista Piloto 13 (direção de 
Achille Tartari, 1929) teria custado 23 contos segundo o seu diretor (GALVÃO, 1975, p. 84), 100 contos estava próximo do orçamento divulgado na imprensa de uma produção muito mais ambiciosa como Escrava Isaura (direção de Antonio Marques Filho, 1929), da Metrópole Film de Isaac Saindenberg. Por esse motivo, não foram construídos muitos aparelhos de projeção Sincrocinex (talvez apenas dois), o que explica porque, em geral, Acabaram-se os otários só foi exibido em uma sala de cinema de cada vez ${ }^{8}$.

Além disso, essas dificuldades técnicas parecem explicar a razão de, no cineteatro Santa Helena, terem sido programadas inicialmente apenas duas sessões por dia, às 14h30min. e 19h30min. Da mesma forma, a trabalhosa projeção torna compreensível a possibilidade de falhas no sistema, como ocorreu na anunciada estreia do filme no Rio de Janeiro. Acabaram-se os otários seria lançado no Cine Rialto em 23 de setembro, uma segunda-feira, mas imprevistos técnicos obrigaram o cancelamento da sessão. Segundo $O$ Paiz, (23 set. 1929, p. 10), o problema foi que, na última hora, "deu-se pela falta de uma peça do aparelho de som".

Segundo o relato do próprio cineasta, a ligação entre o projetor e o toca-discos que deviam executar as partes sincronizadas se dava através de um mecanismo ligando o eixo da manivela do projetor ao eixo da manivela do toca-discos. Isto é, o sincronismo entre os dois equipamentos aparentemente era mecânico e não elétrico, como no Vitaphone e mesmo em processos pioneiros da década de 1910. A parte elétrica, na verdade, ficava restrita ao amplificador ligado por fio a um "alto falante debaixo da tela" (BARROS, 1978: 105). O problema no Rio de Janeiro ocorreu quando se verificou que os projetores utilizados no Cine Rialto tinham uma velocidade diferente daquela a qual tinha sido ajustado o toca-discos do Sincrocinex.

\footnotetext{
8. Numa reportagem elogiosa ao Sincrocinex, comparando-o com os caros projetores importados, o jornal Folha da Manhã fornecia outros valores, talvez mais realistas em relação aos custos do equipamento da produção de Luiz de Barros: "Enquanto os [projetores sonoros] americanos custam 250 contos, os brasileiros podem ser vendidos por trinta" (1 set. 1929: 6). Entretanto, haviam os demais gastos de produção e Paraguassú ([1974] 2000), por exemplo, revelou que ganhou 1 conto e 500 mil réis por sua participação em Acabaram-se os otários.
} 
Assim, o dinheiro dos ingressos vendidos para a sessão de segunda-feira foi devolvido aos espectadores e a estreia carioca adiada em três dias, para a quintafeira, 26 de setembro. A solução era simples, lembrando que o filme alternava sempre uma parte sincronizada com discos com outra projetada sem sincronismo, apenas acompanhamento musical. Por isso, "mudou o projetor (bastava um) e tudo correu bem" (BARROS, [1976] s.d., p. 71).

Entretanto, a ligação mecânica entre o projetor e o toca-discos, jamais absolutamente perfeita, deve explicar a irregularidade dos resultados para o espectador, conforme a avaliação de Octávio Mendes: “o sincronismo do filme é às vezes bom, às vezes mau. Às vezes péssimo" (Cinearte, 18 set. 1929, p. 29).

Nesse mesmo sentido, o bem-informado crítico da sessão "Músicas e Discos" da revista $O$ Malho, espectador assíduo dos talkies exibidos no Quarteirão Serrador, não se impressionou com as alardeadas proezas do Sincrocinex. Na verdade, ele já estava ciente das limitações técnicas do sistema - tido como uma imitação ou deturpação do cinema sonoro estrangeiro - quando foi assistir ao lançamento de Luiz de Barros:

O filme em questão - Acabaram-se os otários - foi precedido de um "reclame" espalhafatoso e logrou atrair boas frequências, o que desmentia, evidentemente, o conceito da película.

Mas nós, que sabíamos da inexistência no Rialto dos aparelhos Vitaphone ou Movietone, não fomos até lá, é claro, para apreciar a "arte cinematográfica brasileira", a "sincronização nacional”, nem o "primeiro filme falado em português".

Fomos, isto sim, ouvir algumas músicas regionais cantadas por Paraguassú e as piadas humorísticas de Genésio Arruda, todas elas gravadas em discos "Columbia" e executadas por uma vitrola, ou coisa que valha, que sabíamos existir por trás da tela, funcionando nos momentos oportunos.

Queríamos ouvi-las no paralelismo, embora defeituoso, do desenrolar da ação, para registrarmos os efeitos porventura alcançados.

No final de contas, o crítico revelou-se sumamente decepcionado com o filme, tendo saído, "como toda a gente, profundamente irritado com a desonestidade 
desses expedientes “artísticos'”. Nem a parte musical mereceu elogios: "E quanto às canções de Paraguassú e as piadas do Arruda, é preferível que os phonóphilos adquiram os discos em que elas se encontram e os escutem em casa, mais comodamente e com a vantagem de repeti-los quantas vezes quiserem..."

Obviamente, o crítico de $O$ Malho se endereçava aos seus leitores das classes médias e altas que tinham condições de comprar os novos discos gravados por processos elétricos vendidos por preços que variavam de 12 a 25 mil réis cada um (de quatro a oito vezes o valor do ingresso do Cine Rialto). Esses mesmos leitores supostamente também já possuiriam em suas confortáveis residências as caríssimas vitrolas que custavam, em média, várias centenas de mil réis.

Por outro lado, grande parte do público popular só tinha acesso então aos discos elétricos por "contrabando". Isto é, somente na rua, no espaço público, é que muitas pessoas podiam ouvir as modernas vitrolas já instaladas em bares, restaurantes e lojas de discos, sendo, por isso, apelidadas de "basbaques da vitrola" (GONÇALVES, 2006, p. 68). Esse aspecto é exemplificado pelo comentário de que "Pagan Love Song" - o tema musical do filme sonoro americano O Pagão (direção de W. S. Van Dyke, 1929), posteriormente parodiado, aliás, por Luiz de Barros em O babão (1931) -, era "a melodia que se ouve frequentemente nos cafés providos de ortophonicas, nos 'halls' dos cinemas e [...] em outros lugares onde se faz música para o público, que pára, esquecido da vida, onde quer que ouça uma vitrola (O Malho, 2 nov. 1929, p. 53). As salas de cinema já haviam se tornado, portanto, uma das primeiras opções de acesso público e pago do grande público à tecnologia dos discos elétricos, sendo possível comprar ingressos não apenas para ver, mas também para ouvir9 9

9. Por outro lado, o crítico musical da revista Phono-arte chegou a reclamar da execução de discos antes das sessões dos filmes sonoros nos bons cinemas já adaptados. Servindo apenas de propaganda para esses discos e pelo fato de já serem exibidos vários "shorts musicais" antes dos filmes, ele não via a necessidade dessa "tal audição discográfica preparatória" (Phono-arte, 15 set. 1929: 28). Entretanto, para o espectador comum que não era "phonóphilo" como o tal crítico, a audição de discos na sala de projeção - assim como nas salas de espera - devia gerar agrado e interesse. Vale lembrar que, àquela altura, cinemas luxuosos como o Odeon e o Palácio Theatro começaram a promover "sessões populares" dos talkies, aos domingos pela manhã, com ingressos a 2 mil réis, destinadas aos "operários e classes menos abastadas" que não tinham tido ainda a oportunidade de conferir a novidade (Gazeta de Notícias, 1 ago. 1929: 5). Ou seja, ingressos mais baratos até do que os cobrados pelo Cine Rialto (onde estreou Acabaram-se os otários) e acessíveis para a baixa classe média, embora ainda dificilmente estivessem ao alcance do proletariado. 
Dessa forma, além do aspecto nacionalista - o primeiro longa-metragem brasileiro falado em português, com músicas caracteristicamente brasileiras -, a atração da sincronização entre som e imagem de Acabaram-se os otários atraía, sobretudo, as plateias populares. Não apenas as pessoas curiosas pela recente revolução da indústria fonográfica e pelas dezenas de discos lançados todas as semanas, mas também espetadores ainda afastados dos talkies pelo alto preço dos ingressos dos cinemas convertidos para o som e/ou pelo desconhecimento da língua inglesa nas versões originais norte-americanas então lançadas nos cinemas brasileiros.

O Sincrocinex, como vimos, era uma atração conjunta (filme, projetor e operador) que levava o cinema sincronizado às plateias que possivelmente ainda não o conheciam, de forma semelhante ao que ocorria nos primórdios do próprio cinema, no período dos exibidores ambulantes entre aproximadamente 1896 e 1907. O anúncio da distribuição do filme deixava isso claro aos exibidores interessados: "Os aparelhos de som serão instalados em poucas horas pelos técnicos da Sincrocinex que acompanham o film, sem ônus para o exibidor" (Correio da Manhã, 17 out. 1929, p. 8).

Luiz de Barros relatou a questão da projeção de Acabaram-se os otários em suas memórias, tratando, inclusive, de minimizar, na realização do filme, o papel do futuro cineasta Moacyr Fenelon, que esteve ligado apenas à sua exibição:

Como o meu aparelho era leve e facilmente portável, eu estava em condições de levar o meu filme falado a cinemas não possuidores de aparelhagem sonora. Para acompanhar e instalar o aparelho nos cinemas, e só para isso, contratei o Moacyr Fenelon, que sequer entrou num local onde eu filmava e nunca teve a menor participação nas filmagens de Acabaram-se os otários. Fenelon foi contratado por mim porque trabalhava numa casa de rádio na Rua Direita, em São Paulo, e por isso entendia bem de amplificadores (BARROS, 1978, p. 105-6).

Essa experiência com o Sincrocinex - andando de cinema em cinema instalando os toca-discos e alto-falantes - seria lembrada pelo próprio Moacyr Fenelon anos mais tarde, embora sem especificar tratar-se dos filmes de Luiz de Barros: 
Já exibi filme brasileiro dentro de automóvel, percorrendo todo o centro e sul do Brasil, com um equipamento sonoro às costas. Era o tempo do vitafone. Chegava às 8 horas da manhã, numa cidade, numa vila. Iniciava imediatamente o trabalhozinho de transformação. Passava o dia adaptando aos projetores mudos a minha aparelhagem ambulante. E à noite, do próprio chevrolata do qual eu arrancara o banco traseiro, controlava o espetáculo que pela primeira vez era oferecido às populações do interior do país (Cine-Rádio Jornal, 25 jun. 1941, p. 4; BARRO, 2001).

\section{Conclusão}

Acabaram-se os otários foi exibido em salas paulistanas até, pelo menos, fevereiro de 1930 (BERNARDET, 1979: s.p.). Entre 1929 e 1930, Luiz de Barros lançou outros filmes de apenas um rolo (cerca de 10 minutos) sonorizados e produzidos pelo Sincrocinex, como Amor não traz vantagem (1929) ou Uma encrenca no Olimpo (1929). Em sua biografia, o cineasta rememorou também o esquete cômico Minha mulher me deixou, que parece se constituir numa cena do próprio Acabaram-se os otários, na qual Tom Bill tenta depenar uma galinha com uma navalha (BARROS, 1978, p. 107). Isso parece indicar que o primeiro longa-metragem da Sincrocinex teria sido desmembrado em curtas-metragens exibidos independentemente como complemento de sessão ${ }^{10}$.

Certamente, Luiz de Barros, Del Picchia e Fenelon levaram o Sincrocinex, ao longo de vários meses, para diversas cidades do interior do Brasil que ainda não conheciam o cinema sonoro ou que teriam um público em potencial para um filme falado em português. Desses programas sincronizados por discos fariam parte também os filmes Lua de Mel (1930) e Messalina (1930).

10. O curta-metragem sincronizado Bem-te-vi, filmado por José Del Pichia com Paraguassú cantando a música título, provavelmente também era parte do filme Acabaram-se os otários, tendo sido posteriormente exibido de forma avulsa. Desse modo, é imperativo corrigir sua datação equivocada - a de que o filme teria sido feito e exibido em 1927 -, informada por Alex Viany (1959: 98) e José Ramos Tinhorão (1972: 249-250), entre outros, e que ainda vem sendo divulgada pela Filmografia Brasileira (www.cinemateca.org.br) e transcrita pelos historiadores de cinema e música. É impossível o filme ter sido filmado em 1927. Além do fato de que teria sido um caso pioneiro de filme sonoro brasileiro do qual haveria registros na imprensa, a Columbia (onde Paraguassú gravou o disco com Bem-te-vi) só inaugurou seu estúdio no Brasil em 1929. Questionado por Alex Viany especificamente a respeito desse curta, o próprio Luiz de Barros (1967) frisou em seu depoimento que Bem-te-vi veio depois de Acabaram-se os otários. 
Por outro lado, a conversão do circuito exibidor em grandes cidades como São Paulo foi rápida ao ponto de, em 1931, Luiz de Barros lançar O babão, um filme inteiramente sonorizado em discos Vitaphone, isto é, em 33 1/3 rpm. Isso representava não apenas a concretização final da possibilidade de finalmente se gravar discos nessa rotação no Brasil (o que foi feito nos estúdios da Odeon), mas também um sinal de que mesmo as salas paulistanas destinadas ao público popular já estavam aparelhadas para exibição de filmes falados no sistema de som em discos. Àquela altura, ao produtor brasileiro bastava fornecer o filme sonoro, não mais o projetor e o operador.

Diferentemente de Acabaram-se os otários, O babão foi “subvencionado" pelo Programa Matarazzo (Diário Carioca, 28 fev. 1931, p. 5), embora Luiz de Barros (1978: 107) tenha dito que o filme só foi comprado por essa agência distribuidora depois de pronto. $\mathrm{O}$ diretor afirmou ainda que o filme foi realizado em 21 dias e custou apenas 21 contos de réis, tendo sido vendido ao Programa Matarazzo por 600 contos (BARROS, 1967) - um valor aparentemente exagerado.

Ainda assim, é significativo que o coprodutor ou comprador do longametragem Sincrocinex de 1931 tenha sido um distribuidor e não mais um exibidor como em 1929. Parece ser um possível indicativo de que, passado o momento mais atribulado da conversão das salas de exibição para o cinema sonoro, os interesses dos produtores brasileiros e dos principais exibidores brasileiros não mais convergissem como naquele encontro casual entre Luiz de Barros e João Antonio Bruno relatado nas páginas de Minhas memórias de cineasta.

Desse modo, tomando emprestados os termos de Paulo Emílio Sales Gomes ([1966] 2001, p. 36), podemos concluir que as turbulências decorrentes do advento do som teriam possibilitado um breve e efêmero momento de solidariedade de interesses entre determinados produtores, exibidores e espectadores ávidos pela novidade do som. Essa convergência teria se cristalizada, em particular, na bem-sucedida realização e exibição de Acabaramse os otários. Passado esse fugaz momento de convergência de interesses, o mercado voltou ao que era antes - essencialmente atrelado ao filme estrangeiro - e $O$ babão, por exemplo, não repetiu o sucesso de seu precursor. E, não por acaso, o filme sonoro seguinte de Luiz de Barros, Carioca maravilhosa, seria feito apenas em 1935 - após um intervalo de longos quatro anos -, já nos estúdios da Cinédia, com gravação de som ótico direto. 


\section{Referências}

ALMIRANTE. No tempo de Noel Rosa. $2^{\mathrm{a}}$ ed. Rio de Janeiro: Francisco Alves, 1977.

BARRO, Máximo. 60 anos de Atlântida: Moacyr Fenelon e a criação da Atlântida. São Paulo: SESC, 2001. Disponível em: < http://www.sescsp.org.br/sesc/hotsites/atlantida/>. Acesso em: 15 abr. 2013.

BARROS, L. Minhas memórias de cineasta. Rio de Janeiro: Artenova: Embrafilme, 1978.

Rio de Janeiro, [1976] s.d. Mimeografado. Acervo Cinemateca do MAM-RJ.

BERNARDET, J.-C. Filmografia do cinema brasileiro: 1900-1935 - jornal O Estado de São Paulo. São Paulo: Secretaria de Cultura/ Comissão de Cinema, 1979.

CAMPOS, C. M.; PERRONE, Rafael. "O Palacete Santa Helena: implantação, construção e arquitetura". In: CAMPOS, Candido Malta; SIMÕES JÚNIOR, José Geraldo (orgs.). Palacete Santa Helena: um pioneiro da modernidade em São Paulo. São Paulo: SENAC: Imprensa Oficial do Estado de São Paulo, 2006.

FREIRE, R. L. Truste, músicos e vitrolas: a tentativa de monopólio da Western Electric na chegada do cinema sonoro ao Brasil e seus desdobramentos. Imagofagia: Revista de la Associación Argentina de Estudios de Cine y Audiovisual, n. 5, abr. 2012. Disponível em: <http://www. asaeca.org/imagofagia/sitio/images/stories/pdf5/n5_pasados_5.pdf>. Acesso em: 3 mai. 2013. . Acabaram-se os otários: cinema e disco na chegada do filme sonoro. In: ENCONTRO SOCINE, 16, 2012, São Paulo. Anais. São Paulo: Socine, 2013. p. 289-399.

GALVÃO, M. R. E. Crônica do cinema paulistano. São Paulo: Ática, 1975.

GOMES, P. E. S. Panorama do cinema brasileiro: 1896-1966. In: Cinema: Trajetória no subdesenvolvimento. 2 ed. São Paulo: Paz \& Terra, 2001.

GONÇALVES, C. K. Música em 78 rotações: "Discos a todos os preços" na São Paulo dos anos 1930. 2006. Dissertação de mestrado. Faculdade de Filosofia, Letras e Ciências Humanas. Universidade de São Paulo, São Paulo.

MORAES, J. G. V. "Polifonia na metrópole: história e música popular em São Paulo”. Tempo, v. 5 , n. 10, dez. 2000. 
NEPOMUCENO, R. Música caipira: da roça ao rodeio. São Paulo: Editora 34, 1999.

SCHVARZMAN, S. Travelogue e Cavação no Brasil Pitoresco de Cornélio Pires. In: COMPÓS, 19, 2010, Rio de Janeiro. Disponível em: <http://compos.com.puc-rio.br/media/gt11_sheila_ schvarzman.pdf>. Acesso em: 6 mai. 2013.

SOUZA, C. R. Resgate do cinema silencioso brasileiro: 27 filmes. São Paulo: Sociedade de Amigos da Cinemateca. Cinemateca Brasileira, 2009. Encarte da coleção de DVDs.

TINHORÃO, J. R. Música popular: teatro \& cinema. Petrópolis: Vozes, 1972.

VIANY, Alex. Introdução ao cinema brasileiro. $1^{\text {a }}$ ed. Rio de Janeiro: Instituto Nacional do Livro, 1959.

\section{Registros sonoros}

BARROS, Luiz de. Depoimento ao Museu da Imagem e do Som. Rio de Janeiro, 23 jun. 1967. Entrevistado por Alex Viany, Plínio Campos e Brício de Abreu. Acervo MIS-RJ.

BILL, Tom. Tango mania. São Paulo: Parlophon, 1929, disco n.12020, lado A; BILL, Tom. A quadrilha. São Paulo: Parlophon, 1929, disco n. 12020, lado B; ORQUESTRA MILITAR PARLOPHON. A serenata malograda. São Paulo: Parlophon, 1929, disco n. 12014, lado B.

PARAGUASSÚ. Talento e formosura. In: PARAGUASSU. A música brasileira deste século por seus autores e intérpretes - Paraguassu. São Paulo: SESC, 2000 (Gravação de show e entrevista concedida a Fernando Faro, em 1974). 